\title{
SUMMARY
}

\author{
LYSINE REQUIREMENTS OF GROWING-FINISHING \\ PIGS ACCORDING TO THE ENERGY RESTRICTION LEVEL, \\ WITH OR WITHOUT FAT INCORPORATION INTO THE DIET
}

In order to study the lysine requirement of the growing-finishing pig, under the conditions of an optimum energy restriction for carcass quality, an experiment was carried out on 8 lots of 14 animals each ( 7 castrated males and 7 females of the Large White breed) between 25 and Ioo $\mathrm{kg}$ live weight. The dietary treatments were applied according to a $3 \times 2$ factorial design : - 3 levels of lysine : 85, Ioo and II 5 respectively, as compared to a level roo of corresponding to the usual recommandations under restricted feeding;

- 2 levels of energy : 3200 and $3450 \mathrm{kcal}$ of digestible energy (DE)/kg diet, through incorporation of $6 \mathrm{p}$. 100 dietary fat (beef tallow) into a cereal diet (barley and wheat) with soybean oil-meal.

The energy/protein ratio was maintained at a constant level in all the diets and through the whole experiment, i.e. 55 to $60 \mathrm{~g}$ crude protein/ $\mathrm{L}$ ooo $\mathrm{kcal} \mathrm{DE}$.

The optimum level of lysine was found to be $3.0 \mathrm{~g} / \mathrm{I}$ ooo kcal DE during the first period of growth $\left(25^{-4} 5 \mathrm{~kg}\right.$ live weight) and $2.5 \mathrm{~g}$ during the finishing phase (45-100 kg), both with females which were liberally fed (up to $9000 \mathrm{kcal} \mathrm{DE}$ at $80 \mathrm{~kg}$ live weight) and with castrated males which were severely restricted $(7500 \mathrm{kcal} \mathrm{DE}$ above $60 \mathrm{~kg}$ live weight). With castrated males, however, the degree of fatness is more related to the level of energy restriction than to the level of lysine. It may appear that these recommendations are highly overestimated, especially during the finishing period. But, conversely it seems that the level of $2.3 \mathrm{~g}$ lysine/ $\mathrm{I}$ ooo kcal $\mathrm{DE}$ is too low during the first phase of growth. On the other hand, a change in the kind of energy source after incorporating animal fat into the diet, has no effect on the amount of lysine required by the pig according to energy.

\section{SUBSTITUTION DU TOURTEAU IOE SOJA \\ DANS DES RÉGIMES DE FINITION \\ PAR LE BLE OU LE MAÖS SUPPLÉMENTÉ OU NON \\ PAR LA L-LYSINE}

\author{
J.-P. BOUARD, J. CASTAING* et M. LEUILLET \\ Institut technique des Cévéales et des Fourrages, \\ 8, Av. du Président Wilson, \\ 75116 Paris \\ * Association générale des Producteurs de Maïs, \\ 1, Place Lestapis, \\ 61000 Pau
}

\section{RÉSUMÉ}

Nous avons réalisé deux expériences afin de mesurer l'épargne possible de tourteau de soja et les conséquences d'une réduction du taux azoté dans les conditions d'emploi de régimes énergétiques à base d'une seule céréale : le blé ou le maïs. 
L'étude a porté sur la seconde partie de la croissance des animaux en raison du "poids " alimentaire qu'elle représente (environ les $2 / 3$ de l'alimentation du porc charcutier) et de la faiblesse numérique des informations sur les divers besoins du porc pendant cette période.

En outre afin de tenir compte de la diminution des apports azotés qualitatifs induits par la réduction de la part du tourteau de soja, nous avons effectué pour certains lots, une supplémentation en L-lysine industrielle.

Dans nos conditions expérimentales (alimentation libérale en croissance et rationnée en finition) l'emploi de régimes "haute énergie " à base de blé ou de mais a conduit aux résultats suivants:

- La réduction en finition du taux azoté à I3-14 p. Ioo permet une économie de 25 p. Ioo du tourteau de soja par porc engraissé, comparativement aux régimes témoins "aux normes".

- La supplémentation en lysine pendant la finition ne présente pas d'intérêt car la substitution de la moitié du soja complémentaire par les céréales seules n'a pas limité significativement les performances zootechniques.

\section{SUMMARY}

\section{SUBSTITUTION OF SOYABEAN OIL,MEAL, IN FINISHING \\ PIG DIETS BY WHEAT OR MAIZE SUPPLEMENTED OR NOT WITH L-LYSINE}

Two experiments were realized in order to measure the possible sparing of soyabean oilmeal and the consequences of reducing the crude protein level when using energetic diets based on one only cereal (wheat or maize).

The study was made during the second growth phase of the animals because of the volume of food involved during this period $(2 / 3$ of the food required for growing-finishing pigs) and the small number of data available on the requirements of pigs during this growth phase.

In addition, reduction of soyabean oil-meal leading to a decrease in the qualitative supply of crude protein, some of the groups were supplemented with industrial L-lysine.

In our experimental conditions (ad libitum feeding during growing and restricted during finishing), the utilization of highly energetic diets based on wheat or maize led to the following results :

- During the finishing period, reduction of the crude protein level to I3-I4 P. roo allowed a sparing of 25 p. Ioo soyabean oil-meal per pig fattened, as compared to the standard diets (controls).

- Lysine supplementation during finishing did not present any advantages since substitution of half of the complementary soyabean by cereals alone did not significantly limit the performances. 